\title{
O CENSUAL NO CORPO DA LETRA
}

\author{
Carlos Eduardo Schmidt Capela \\ $\mathrm{UFSC} / \mathrm{CNPq}$
}

RESUMO: 0 ensaio contrapõe a peça Bent, de Martin Sherman, estreada em 1979, e o filme nela baseado (1997) para, a partir daí, pensar as situacões de opressão, tendo como ponto de fuga a novela de Samue Rawet, Viagens de Ahasverus à terra alheia em busca de um passado que não existe porque é futuro e de um futuro que já passou porque sonhado.

PALAVRAS-CHAVE: Bent. Viagens de Ahasverus. Opressão.

\section{THE CENSUAL IN THE BODY OF THE LETTER}

ABSTRACT: The essay opposes the play Bent, by Martin Sherman, performed for the first time in 1979, and the movie based on the play (1997), in order to think, thus, the situations of oppression, having as a vanishing point the novel written by Samuel Rawet, Viagens de Ahasverus à terra alheia em busca de um passado que não existe porque é futuro e de um futuro que já passou porque sonhado.

KEYWORDS: Bent. Viagem de Ahasverus. Oppression.

Carlos Eduardo Schmidt Capela |capela@cce.ufsc.br | é professor de Teoria Literária no Departamento de Língua e Literatura Vernáculas e professor do Programa de Pós-Graduação em Literatura da Universidade Federal de Santa Catarina. Pesquisador CNPq. 


\title{
O CENSUAL NO CORPO DA LETRA
}

\author{
Carlos Eduardo Schmidt Capela
}

Serei sempre estranho a mim mesmo. Albert Camus. O mito de Sísifo

Estreada em Londres, no ano de 1979, a peça Bent, de Martin Sherman, foi pela primeira vez encenada no Brasil em 1981, sob a direção de Roberto Vignati. A montagem alcançou amplo sucesso, de público e de crítica, decorrente, em boa medida, e isso para além dos seus méritos cenográficos, da matéria efervescente por ela trazida à tona. Centrada na relação homossexual entre dois prisioneiros de um campo de concentração - um dos quais assume a homossexualidade frente aos carrascos nazistas, sendo por isso identificado pelo infame triângulo rosa costurado no peito de seu uniforme, enquanto o outro, por sua vez, faz o possível para ocultá-la, dizendo-se "apenas" judeu, o que o leva a portar em sua roupa a não menos infame estrela amarela - , a peça, afinal, respondia com propriedade a um crescente sentimento de repulsa ao regime militar que se seguiu ao golpe de 1964, naquele momento ainda em vigência no país.

Vale lembrar, para caracterizar com breves traços o clima político então dominante, que 1981 é o ano da tentativa de atentado ao show em comemoração ao Dia do Trabalho - promovido pelo Centro Brasil Democrático, e compartilhado por diversos artistas e por um enorme público -, ocorrida na noite de 30 de abril, no Rio de Janeiro. Na ocasião dois militares não tiveram êxito em sua missão de instalar, nas dependências do Riocentro, local da comemoração, explosivos cuja detonação estava prevista para acontecer durante o espetáculo, incidente esse que, se tivesse sido bem sucedido, poderia fornecer motivos suficientes para o retorno da "linha dura" (esse pelo menos parece ter sido o cálculo de estrategistas dos serviços de inteligência do exército), como era chamado o período mais radical da repressão aos que combatiam a ditadura, ou simplesmente a ela se opunham.

O fracasso no atentado do Riocentro, cujo inquérito, inconclusivo, foi arquivado ao final de meros quatro meses de grosseiras averiguações (para 
tanto forjou-se, no plano textual, uma ficção com um roteiro pessimamente amarrado, repleta de contradições irresolvidas, que no plano factual foi complementada por uma derrisória encenação teatral, em eventos públicos ou diante da mídia, por parte de alguns dos militares responsáveis pelas investigações, algo que ficou demonstrado em 1999, quando o caso foi reaberto e uma pequena parcela dos responsáveis indiciados, porém não condenados, isso por conta de uma absurda extensão da lei de anistia), o fracassado atentado no Riocentro desembocou numa considerável crise política, que pode ser resumida pelo pedido de demissão do General Golbery do Couto e Silva, na época um dos homens de maior influência no governo. Essa perda de força do regime não deixa de ser reafirmada, no plano cultural, pela oportuna encenação de Bent.

Oportuna, com efeito, porque a peça aborda alguns problemas fundamentais no âmbito da modernidade ocidental, isto é, no desdobramento desse longo processo de consolidação do pensamento e de práticas autoritárias que se segue ao clarão encegueirado do centralismo iluminista. Em particular, problemas inerentes a relações entre indivíduos, de um lado, e, de outro, instituições, ou melhor, corporações, ou seja, organizações cujo poder é função direta de sua habilidade em incorporar, pelo viés da aceitação ou da repulsa, mesmo da eliminação, aqueles indivíduos, tolhendo assim sua potencial liberdade, e responsabilidade, de ação e de escolha. O primeiro destes problemas diz respeito a processos de identidade e de identificação.

A observação de Siegfried Kracauer acerca da intrincada correlação entre a Convenção do Partido Nazista, em Nuremberg, e o filme realizado a partir dela, por Leni Riefenstahl, quando afirma que a produção de Triunfo da vontade (1935) é produto de uma encenação expressamente produzida para resultar nesse mesmo filme ${ }^{1}$, de modo que ao final não conseguimos saber se o filme é produto da convenção ou esta produto daquele, reafirma, em senda semelhante àquela antes indicada por Walter Benjamin², a importância vital do estabelecimento de uma política relativa à manipulação de imagens por parte de qualquer sistema ditatorial, uma de cujas prévias o mesmo Kracauer

\footnotetext{
1 KRACAUER, Siegfried. Supplement - Propaganda and the Nazi War film. In: From Caligari to Hitler: a psychological history of the German film. Ed. Leonardo Quaresima. Princeton: Princeton UP, 2004, p. 301.

2 BENJAMIN, Walter. A obra de arte na era de sua reprodutibilidade técnica. In: Magia e técnica, arte e política: ensaios sobre literatura e história da cultura. Obras escolhidas, v. I. Trad. Sergio P. Rouanet. São Paulo: Brasiliense, 1985, p. 165-196.
} 
localizara, em seu polêmico estudo sobre Jacques Offenbach ${ }^{3}$, na França de Luís Felipe. Em situações ou momentos como tais ocorre a imposição, e a reiteração, de um conjunto de práticas rituais cujo modo de operação, para falar com Marie-José Mondzain, deriva do antigo processo cristão da eucaristia, uma "liturgia do dispositivo fusional", realizada pela igreja, que tem a função de gerar "visibilidades programáticas, feitas para comunicar uma mensagem unívoca" com o intuito de, a partir daí, promover a incorporação dos indivíduos, ou sua definitiva exclusão, fruto da imposição de uma identificação plena e fechada com a comunidade assim comunicada. No domínio particular do nazismo, conforme Mondzain, as intervenções propagandistas são organizadas com base numa radicalização do princípio eucarístico, o que ao final acarreta a implicação da própria vida no cerne de uma política voltada ou devotada à morte, uma bio-política que na verdade realiza uma tanato-política, isso na medida em que o governo, no caso, "não se contenta em usar símbolos e emblemas já existentes, mas sobredetermina-os a fim de impor um regime único de interpretação e manipular conjuntamente o desejo de matar e o de morrer." 4

A partir de proposições como estas torna-se possível compreender algumas das razões pelas quais, em Bent, impressiona o vigor intenso adquirido pelas insígnias que identificam as duas personagens protagonistas, a estrela amarela e o triângulo rosa, de um lado, e, de outro, a suástica, a significar nazismo e nazistas.

No ensaio "Sobre a pintura ou Signo e mancha", de 1917, ao refletir sobre o signo, em particular sobre a sua caracterização com base na significação que nele introduzem as linhas, o jovem Walter Benjamin observava, no caso da linha gráfica oposta à superfície sobre a qual é traçada, que esta oposição ou aposição possui não apenas significação visual, mas também metafísica. Porque, como sublinha o autor, o próprio fundo é ordenado por tal modalidade de linha, que deste modo "designa a superfície e com isso a determina na medida em que se ordena a si mesma, como também a seu fundo." ${ }^{5}$ Unicamente existindo sobre e graças a este fundo, a linha gráfica confere a ele "identidade",

\footnotetext{
3 KRACAUER, Siegfried. Jacques Offenbach and the Paris of his time. Trad. Gwenda David e Eric Mosbacher. New York: Zone books, 2002.

4 MONDZAIN, Marie-José. A imagem pode matar? Trad. Susana Mouzinho. Lisboa: Nova Vega, 2009, p. 27, 33 e 63 respectivamente.

5 BENJAMIN, Walter. Sobre a pintura ou Signo e mancha. In: Escritos sobre mito e linguagem (19151921). Trad. Susana Kampff Lages. São Paulo: Duas cidades/Editora 34, 2011, p. 81-82.
} 
pois ao determinar-se ela ao mesmo tempo proporciona a caracterização da superfície sobre a qual é traçada, ligando-se a essa enquanto o fundo que e a que dá lugar. Benjamin postula, assim, que linha (ou desenho) e fundo se implicam e se imbricam através de uma sutil e recíproca determinação, relação essa cuja complexidade demanda especial atenção.

Caso seja pertinente estender para a esfera dos signos propriedades que o ensaísta atribui às linhas gráficas, cujo estabelecimento é função do fundo por elas estabelecido, o qual, por sua vez, "assume um lugar determinado e indispensável ao sentido do desenho", de maneira que "duas linhas só podem determinar sua relação mútua por comparação com seu fundo" ${ }^{6}$, no caso de esta extensão ser factível dois signos, como, em Bent, a estrela amarela e o triângulo rosa, traçados sobre um mesmo fundo, constituído, na peça, pelo pano de fundo, ordinário, do uniforme reservado aos prisioneiros, embora diferenciados, ou porque diferenciados, fazem ressaltar justamente esse fundo que destacam no processo mesmo de dele se destacar, e destacar-se mutuamente. E porquanto o signo, ainda conforme Benjamin, provém de ou é posto por uma potência exterior (o "fato de o signo ser impresso, de fora para dentro"7), esse fundo, esse pano de fundo esgarçado não deixa de remeter ao nazismo e, por extensão, a todo modelo de autoritarismo, podendo ser tomado ou como reafirmação da suástica e do mundo por ela regulado, ou como sua problematização, sinalizando, por exemplo, para a sua depravada natureza maniqueísta.

O pano de fundo encardido introduz, mesmo à revelia, uma potência de desvio em relação ao lugar comum que ele tanto se aplica em afirmar, constituindo aquilo que precisaria ser pensado, e precisa ainda, isso inclusive na medida em que ele dá lugar a diferenças que de maneira alguma se sustentam fora do âmbito em que ele, o pano de fundo do nazismo, soberano e sobredeterminado, impera. Em meio à sujeira que desde sempre o caracteriza sobressai o lampejo de um alerta com relação ao imperativo de que identidade não pode em absoluto ser confundida com identificação, ao menos se o que se quer é evitar a aceitação de uma abjeta objetivação, isto é, de uma naturalização cujo matiz e cuja matriz remetem ao universo da técnica.

Levando-se também em conta, outra vez de acordo com Walter Benjamin,

\footnotetext{
Ibidem, p. 82.

Ibidem, p. 83.
} 
que o signo implica, antes de mais nada, uma relação espacial, uma localização específica, aludindo a uma situação individual (já que ele se liga "mais à pessoa" $^{8}$ ), cada situação individual assinalada, cada estigma exige ser considerado tendo em vista o tecido que o informa, uma meticulosa atenção com respeito à maquinaria a que a linha ordinária obedece ao traçar o pano, um zelo particular tanto pelo alinhavo quanto pelo alinhamento, sob o risco de, em caso contrário, incorrer-se na reafirmação simplória da lógica exclusiva que o pano exala e exalta. Por isso o signo, para Benjamin, não ser um meio, isto é, uma passagem entre ordens que assim se tornariam comensuráveis, ou redutíveis umas às outras. Desde a perspectiva benjaminiana, o signo, ao invés, pertence a, ou apresenta, "uma ordem que, por enquanto, muito provavelmente, nos é totalmente desconhecida" ${ }^{9}$, ordem essa que necessita ser considerada desde o domínio da política, portanto da ética, da literatura e da arte, nunca porém desde aquele do mito. ${ }^{10}$ Ao se prestar à impressão tanto sobre os viventes quanto sobre os objetos inanimados, nos quais "deixa sua marca"11, o signo, afinal, tende a operar em prol de uma confusão entre esses âmbitos, o que abre uma inquietante possibilidade de que venha a resultar, daí, a atribuição de um incremento de energia simbólica ao já vigoroso poder de antemão conferido à máquina ou aparelho ${ }^{12}$ que o imprime.

O dilema identitário que se arma em Bent reclama ser examinado com base em imbricamentos teóricos como tais, em especial a conclusão da peça, quando uma das personagens troca a blusa de seu uniforme, na qual se destacava a estrela amarela que a identificava como judeu, pela blusa de seu amante assassinado, marcada com o triângulo rosa, antes de se suicidar, para um muito provável desconforto de Albert Camus, se ele tivesse a ela assistido. Porque o que resta preservado em tal situação cênica, independente dos signos, e talvez dos corpos, é o pano de fundo, e nele, indelével, a violenta força

\footnotetext{
8 Ibidem, p. 83.

9 Ibidem, p. 82.

${ }^{10}$ Mito aqui entendido segundo a perspectiva de Jean-Luc Nancy, exposta em "El mito inter-rumpido". NANCY, Jean-Luc. El mito interrumpido. In: La comunidad desobrada. Trad. Pablo Perera, Madrid: Arena, 2001, p. 81-129.

11 BENJAMIN, Walter. Sobre a pintura ou Signo e mancha, op. cit., p. 83.

12 A noção de aparelho (ou aparato) remete a Jean-Louis Déotte, que brevemente o define, em La época de los aparatos (Trad. Antonio Oviedo. Buenos Aires: Adriana Hidalgo, 2013, p. 27), como "la mediación entre el cuerpo (la sensibilidad afectada) y la ley (la forma vacía universal) que Schiller designaba forma soberana. La ley, que no debe entenderse aquí en un sentido limitado, jurídico, es aquello por lo cual, gracias a un aparato, el cuerpo parlante se abre a lo que él no és: el acontecimiento" (aqui, como nas demais citações, os itálicos são dos originais transcritos).
} 
da impressão. Na cena, com efeito, identidade e identificação estão perigosamente próximas, sobrepostas ou borradas, o que a princípio facilita a proposição de uma leitura ingênua que se satisfaça em justapô-las, de forma pouco crítica, com o que o sacrifício de um dos polos nada mais faria que reforçar, senão o outro, pelo menos uma sutil e nada banal inclinação à inevitabilidade de uma fatídica submissão a tudo aquilo por ele impingido. Um episódio como o de Numancia assombra tal cena, como uma sorte de aparição indesejada ainda que de algum modo invocada.

No arranjo implicado pela imolação da personagem, o nazismo arrisca manter-se preservado na segurança de uma distância cujo franqueamento aparenta ser difícil, senão impossível, como se imperasse incólume num território em que vige uma espécie de "nolli me tangere" que, talvez, nada mais faz que reverberar, junto com a impalpabilidade dali advinda, o poder insuportável reivindicado e exercido por ele como próprio e legítimo. Caso tomado exclusivamente como uma corporação identificadora, que permanece não identificada, mas apenas aludida, figurando ao modo de um pano de fundo cujo intento é menos o de dar-se a ver do que o de dar a ver tudo aquilo nele enquadrado, ou por ele capturado, o nazismo pode ser analisado com base na categoria do "distinto", tal como proposta por Jean-Luc Nancy. Isto é, como emanação de uma força colocada fora de alcance e que se encontra separada "do contato e da identidade", uma força que "não toca, e é dessemelhante". ${ }^{13}$ O nazismo, enfim, confina aqui com certa concepção de imagem, essa "coisa que não é a coisa"14, puro empuxo que se mantém retirado e no entanto se deixa atravessar pelo sacrifício, que, enquanto transgressão legitimada, como assinalou Georges Bataille, de algum modo pode abrir espaço para uma reversão que finalmente conduza a uma assunção imaginária do nazismo como mera fatalidade, ou inevitabilidade, em especial se também a ideia de sacrifício for tomada de maneira superficial.

A peça não se exime de sugerir que o nazismo, graças ao imenso poder de distinção por ele logrado, porém distinção sem fundamento, posto que ela opera, a exemplo do que ocorre em qualquer sistema de significação, a partir do preenchimento arbitrário de um significante a priori desprovido de sentido,

\footnotetext{
${ }^{13}$ NANCY, Jean-Luc. L'image - le distinct. In: Au fond des images. Paris: Galilée, 2003, p. 12. (As traduções de originais inéditos em português são de minha responsabilidade)

14 Ibidem, p. 13.
} 
a peça sugere que o nazismo não apenas constitui como incrementa a distinção do distinto. Ele separa, e se separa, "através de marcas", para retomar outra sugestão de Jean-Luc Nancy. ${ }^{15} \mathrm{O}$ nazismo aparece então como uma corporação que estabelece a ordem do estigma, marcando a ferro, cortando ou tatuando tudo aquilo que uma linha, ou um traço, retira e, ao retirar, se retira, com o que procura se acercar do território do intocável e do impalpável, dissolvendo-se naquele fundo que coloca em questão o pensamento.

Nesse contexto, o totalitarismo nazista se define, e se reforça, ao estabelecer e extrair de seu mundo, ou extirpar do campo de visão por ele fixado como o recorte de mundo que lhe é compatível, os párias dos quais necessita para se manter em vigor, e, ademais, para suportar a política racista e higienista que sustenta e o sustenta. Violento e violentador, ele impõe "a realidade" do judeu e do homossexual, ou do negro, da prostituta, do comunista ou da cigana, de qualquer um dentre estes outros quaisquer, a partir do estigma com que os marca, como representações que tornam visível o abjeto com que são marcados. Abjeto cujo negativo, ou melhor, cujo fantasma, por sua vez, projetando-se desde o mesmo pano de fundo, desenha a abjeção do próprio aparelho que neles e com eles marca-se e se faz remarcar. Homossexual e judeu passam assim a constituir manifestações puras da imputação: para isso são usados, e tal uso institui, no campo de concentração, uma continuidade ou homogeneidade resultante de uma única operação de coisificação, com a diferença de que, enquanto aqueles são involuntariamente reduzidos a meros objetos, os que apoiam e alimentam o nazismo aceitam e optam por ser reduzidos a instrumentos submetidos a uma máquina que de modo similar também os subsume.

Por isso, em Bent, o apenas aparente absurdo da ocupação imposta aos dois prisioneiros, um verdadeiro trabalho de Sísifo que, no entanto, nada mais faz que mascarar, e assim manifestar, aquele uso efetivo ao qual eles se prestam. O interminável exercício de carregar pedras de um lugar para outro, para depois trazê-las de volta, de novo amontoá-las, e levá-las, e trazê-las, essa repetição que parece arrasar qualquer possibilidade de sentido estabelece, não sem alguma sutileza, uma razão que pouco difere da razão ordinária do cons-

15 Ibidem, p. 12. 
trangimento humanista. É fácil depreender que o resultado visado não demora na ideia do trabalho enquanto atuação sobre o mundo material, com o fim mais ou menos nobre de satisfazer alguma necessidade, e tampouco leva a uma identificação, digamos, "funcional", daqueles que o exercem (não custa lembrar que muitos nomes ocidentais derivam de ocupações e ofícios, prova disso são os inúmeros Santeiros, Shumachers, etc). Com o inegável propósito de "aviltar e de degradar para nihilizar"16, esse trabalho literalmente forçado, esse trabalho sem fim implica, ao contrário, na reafirmação da pura violência, da imagem e da força da violência que apenas arruína e massacra tudo que o nazismo mesmo afirma ser-lhe heterogêneo, com o que ele, no modo performativo que lhe é tão caro, "declara sua irrupção como a própria figura, a imagem do que está fora". ${ }^{17}$ Ou seja, como uma manifestação de poder que estabelece um sistema de exceção ao dele se retirar, para deste modo o impor e através dele se impor.

É nesse sentido que pode ser afirmado que o nazismo, a exemplo de todo e qualquer sistema totalitário, opera tendo como fim a reafirmação da imagem que procura irradiar de si mesmo, alardeando um seu suposto poder insuportável. Fazendo uso de um autotelismo radicalmente distinto daquele característico dos regimes artísticos, ele, sobretudo no campo, impõe uma lógica que visa à humilhação. O interminável trabalho de carregar pedras de cá para lá embute o terminar com a disparidade, e, junto com ela, exterminar toda e qualquer singularidade possível. O absurdo nada tem de absurdo, ou, por outra, é racional ou logicamente absurdo, e por isso mais letal ainda.

É com base em raciocínios como tais que se torna possível ressaltar, em Bent, por outro lado, a felicidade da cena em que os amantes estigmatizados, impedidos de se tocar, têm sucesso em uma cópula à distância, atingindo o gozo ao final de um ato sexual realizado apenas com a mediação das palavras e de seus impulsos, que ativam a memória: o corpo da palavra, corpo de letra, e o corpo dos sentidos sensatos e sensíveis são ali reunidos, poética, física, ética, politicamente, e, soberanos, agora na acepção de Georges Bataille, esvaem-se em jactância, um ejacular que resume o impalpável da resistência. O sensual que emana do corpo, então, supera o censual, o censo e a censura do controle, escapando, jorrando para fora do organismo que os mecanismos

\footnotetext{
16 JANKÉLÉVITCH, Vladimir. Pardonner? In : L'imprescriptible. Paris: Seuil, 1986, p. 24.

17 NANCY, Jean-Luc. L'image - le distinct, op. cit., p. 37.
} 
de contenção se obrigavam e se obrigam a submeter no grau mais absoluto. É importante ressaltar que nessa cena, ao menos na montagem de 1981, no Brasil, as personagens apareciam nuas (a nudez frontal de um ator masculino causou inclusive uma razoável celeuma; já no filme baseado na peça, que mantém como título o Bent do original, lançado em 1997 e dirigido por Sean Mathias, os atores estão apenas sem a camisa, o que aumento o peso do censual em detrimento do sensual), isto é, entregues em sua nudez à paixão de seus corpos, de suas palavras e de seus desejos, livres do uniforme que trazia os signos dos estigmas com que eram marcados.

Walter Benjamin, no mesmo "Sobre a pintura ou Signo e mancha", como o título do ensaio explicita, reflete também sobre o conceito de mancha, que constitui o correlato com o qual o signo entretém uma tensão polar. A oposição entre a natureza do signo e aquela da mancha, que para o autor, "de um ponto de vista metafísico é de imensa importância" ${ }^{18}$, e, por certo, de igual modo de um ponto de vista político, estabelece-se sobretudo no quiasma entre espaço e tempo. Enquanto, como visto, o signo faculta uma relação espacial e, portanto, individual, a mancha, para Benjamin, "parece possuir uma significação mais temporal, excluindo praticamente qualquer aspecto pessoal". ${ }^{19}$ Enquanto aquele provém do exterior, esta provém do interior, e aflora, por assim dizer, à superfície, a que não marca e tampouco estigmatiza, ao menos se não for considerada um "prodígio da impressionabilidade", ou seja, um sintoma de histeria, por exemplo, tal como estudado por Georges Didi-Huberman a partir da clínica de Charcot, e de seus contemporâneos, sob o influxo do advento e dos desdobramentos técnicos da fotografia. ${ }^{20}$

A mancha, então, funciona como meio, possui papel mediador, possibilitando divisar à flor da pele, no enrubescimento, por exemplo, correspondências passíveis entre o interno e o externo, o contato e o contágio do exterior com o que e pelo que emerge do interior. Sempre absoluta, a mancha concerne antes de tudo à dimensão humana: enquanto expressão de uma singularidade, de uma força íntima, ela é o "transporte imediato" de uma paixão, para mais uma vez ecoar Jean-Luc Nancy. Que, embora em "A imagem - o distinto" reflita em especial sobre a imagem, não deixa de ter em mira o fenômeno da

\footnotetext{
18 BENJAMIN, Walter. Sobre a pintura ou Signo e mancha, op. cit., p. 83.

19 Ibidem, p. 83

20 DIDI-HUBERMAN, Georges. Le sang, le sens et la sentence. Une brève histoire du 'corps-cliché'. In: L'image ouvert: motifs de l'incarnation dans les artes visuels. Paris: Gallimard, 2007, p. 287-321.
} 
mancha. E Nancy prossegue, no mesmo ensaio, destacando que ela, a imagem, ao atuar como mancha, traz para o plano das aparências tensões que de outro modo poderiam permanecer ocultas. Ela torna possível à intimidade ser expressa, o que faz com que o íntimo acabe por ligar-se profundamente à própria imagem, pois "menos que a tradução de um estado de alma", ele

é a alma mesma que pressiona e que se apoia sobre a imagem, ou, sobretudo, a imagem é esta pressão, esta animação e esta emoção. [...] Ela não é, portanto, uma representação: ela é uma impressão do íntimo e de sua paixão (de seu movimento, de sua agitação, de sua tensão, de sua passividade). ${ }^{21}$

Antes de ser uma impulsividade que se traduz em marca, a mancha-imagem constitui uma pulsação transitória de um pulso ou impulso, é uma fusão ou confusão que nos ocorre, algo que tem a rara propriedade de nos fundar e por vezes afundar.

O ensaio de Walter Benjamin parte do signo e da mancha para chegar até uma reflexão sobre a pintura, enquanto o de Nancy tem como ponto de partida relações entre imagens e sentidos. Os dois autores, no entanto, coincidem numa vigorosa negação à vigência, no domínio das artes, de uma oposição ou distinção radical entre forma e fundo. Para Benjamin, com efeito, na "pintura não existe fundo, nem há nela linha gráfica"22, e Nancy, por sua vez, em sua rápida análise de uma tela de Hans von Aachen, "Jeune couple", observa que nela, assim como em todas as demais pinturas, "o fundo desaparece", e, "desaparecendo como fundo, ele passa integralmente na imagem". ${ }^{23}$ O "eu", com isso, o estritamente pessoal, segundo ele, torna-se "a dissonância de um acorde, a impulsão de um passo de dança. 'Eu': não é mais questão de 'eu'. Cogito se torna imago". ${ }^{24}$ A mimesis desdobra-se assim em methexis, ensejando participação e contaminação.

Tendo em conta as proposições dos dois autores, não é difícil depreender que o exercício sutil da arte opera a partir da desativação e da abolição da ideia mesma de fundo, entendido enquanto um campo concentrado que faculta e facilita a irrupção de sistemas a princípio "racionais" de mecanismos de distinção que, ao desandarem em práticas, impõem aos corpos, às lingua-

\footnotetext{
${ }^{21}$ NANCY, Jean-Luc. L'image - le distinct, op. cit., p. 20-21.

22 BENJAMIN, Walter. Sobre a pintura ou Signo e mancha, op. cit., p. 85.

${ }^{23}$ NANCY, Jean-Luc. L'image - le distinct, op. cit., p. 23.

${ }^{24}$ Ibidem, p. 26-27.
} 
gens e às coisas tão somente a marca indelével de sua violência e de sua violação unívocas. Ao aproximar a mancha ao apelo de uma culpa, que, por seu turno, demanda uma expiação, a análise levada a efeito por Walter Benjamin permite que seja entrevisto, no gozo que atravessa as personagens na célebre cena sexual de Bent, uma espécie de expiação de uma falta, que, como fundo evanescente, com ele e nele desaparece, revolvendo-se e se dissolvendo, assim se resolvendo como nada mais que passagem, transição ou impressão, em suma, sensação.

Com sua habitual perspicácia, o autor leva o raciocínio até o limite de suas consequências, assinalando que a
conexão entre culpa e expiação é, do ponto de vista temporal, mágica, [e] essa magia temporal aparece sobretudo na mancha, no sentido em que a resistência do presente entre o passado e o futuro é eliminada, irrompendo passado e fu- turo numa conexão mágica sobre o pecador. ${ }^{25}$

A personalidade, com isso, prossegue o estudioso, desintegra-se "em certos elementos primitivos" que excluem aspectos puramente individuais. A mancha, em outros termos, ao se lançar para além da simples representação, revela-se irredutível à marca, ao estigma e à culpabilização. O gozo, então, como a culpa, manchas que são, não identificam e tampouco determinam de uma vez por todas. Não são os judeus e tampouco os homossexuais os únicos que gozam: goza-se, corpos gozam e enrubescem, e esse gozo e esse rubor, que perpassam os seres e a história e chegam até aqui rumo ao devir, abalam o poder que os quer sufocar, e a nós expiam.

Uma novela publicada em 1970, um dos experimentos ficcionais mais radicais jamais realizados na língua portuguesa, "Viagem de Ahasverus à terra alheia em busca de um passado que não existe porque é futuro e de um futuro que já passou porque sonhado", legada por Samuel Rawet, ajuda a introduzir outros elementos porventura pertinentes para a discussão aqui ensaiada.

O ano de 1970 costuma ser no Brasil imediatamente associado, e isso não sem um orgulho nacionalista algo tacanho, à conquista do tricampeonato na Copa do Mundo de Futebol, no México. Mas 1970, não custa lembrar, é também o ano em que foi estabelecida a censura prévia a espetáculos e publica-

${ }^{25}$ BENJAMIN, Walter. Sobre a pintura ou Signo e mancha, op. cit., p. 84. 
ções; em que foi instituído o Centro de Inteligência do Exército (o CIE que, aliás, teria papel central no frustrado atentado no Riocentro), além do famigerado DOl-Codi, em cujas instalações país afora muita gente foi torturada, não poucos até a morte; em que ocorreu a Operação Registro, que resultou no aniquilamento da guerrilha no Vale do Ribeira; em que foi realizado o sequestro de Nobuo Okuchi, cônsul do Japão, de Ehrenfried von Holleben, embaixador alemão, e de Giovanni Enrico Bucher, embaixador suíço; entre outros acontecimentos de naipe semelhante.

Eventos como tais não deixam de repercutir nas "Viagens de Ahasverus", que têm como uma de suas matérias o tempo, que já desde o título se apresenta comprimido no ínfimo do instante inapreensível, resumo da terra alheia sempre buscada e nunca alcançada, uma mirífica canaã em permanente reconstrução, em movência constante. Essa impropriedade, território comum, desdenha qualquer possibilidade de posse e controle, dado que nele o passado é função de uma memória por vir, e o futuro nada mais é que um sonho que jamais pode ser declinado senão no passado. Um tempo lendário, insondável, ou seja, narrativo ou imaginado, composto por ações e reflexões fragmentadas, avessas a quaisquer lógicas de antemão fixadas. Um tempo em errância e da errância, em que nada conclui ou se conclui de uma vez por todas, embora toda a matéria, em suas conformações as mais variáveis, assim como a totalidade dos seres e dos entes e, com estes, o indefinido de percepções e afeições que possam vir a despertar, permaneçam como um resto especial, que demanda ser explorado. Pois para o Ahasverus da novela de Samuel Rawet o mundo constitui uma reserva, imensa, que lhe fornece incontáveis matrizes eventuais. Cada acontecimento guardado na memória, e, ainda, cada acontecimento passível de existência verbal figura para ele como termo potencial de uma série de operações de derivação, realizadas nos moldes da função derivada, e, em seu reverso, da função integral, essas fabulosas construções da matemática que, no limite, definem nada mais que curvas, constituindo esboços de tendências, ou inclinações, de qualquer maneira ponderações fundadas em imponderáveis.

O próprio protagonista, Ahasverus, o judeu errante, é uma excrescência, um ser que ao modo de uma mancha irrompe desde as entranhas da história cristã oficial. Alguém amaldiçoado, por ninguém menos que Cristo - chamado, na novela, de Nazareno, nome tido ali como uma simples derivação de Nazaré - , e condenado ao exílio o mais abominável impossível, aquele que o 
livra a um tempo tornado para ele ilimitado, tempo de divindades, prometeico, no qual a morte lhe é furtada, condição que o obriga a manter-se entre os viventes até o juízo final.

É pertinente sublinhar o fato de Ahasverus ser personagem de um vasto número de escritores e artistas. Frequenta textos e imagens diversos, não se deixando confinar por fronteiras de gênero, e tampouco por fronteiras temporais ou nacionais, já que tais textos e imagens foram realizados em diferentes momentos da história, em regiões distintas. Ele, por isso, cumpre, ao menos no plano da arte, e não sem uma sugestiva ironia, o mito que lhe deu nascimento, errando, constituindo o próprio erro a perambular por espaços e tempos absorvidos e absolvidos pelas palavras.

Ahasverus aparece inclusive como personagem emblemática na reflexão tecida por Siegfried Kracauer sobre o conceito, e o problema, da História. É a encarnação - e não podemos nos esquecer, conforme ressalta Marie-José Mondzain, de que apenas "a imagem pode encarnar" ${ }^{26}$ - , Ahasverus é a encarnação na qual se reúnem todas as últimas coisas antes da última, como reza o subtítulo do livro de Kracauer, "The last things before the last", que o imagina, com sua aparência "indizivelmente terrível", como o único indivíduo que "teria um conhecimento de primeira mão sobre os desenvolvimentos e as transições, pois apenas ele, em toda a história, teve a involuntária possibilidade de experimentar os processos do devir e da decadência." 27

Essa unicidade posta em relevo por Kracauer, que incide sobre Ahasverus dotando-o de uma singularidade quase absoluta, é afastada na novela assinada por Samuel Rawet graças ao fato de que ele, ao longo de suas inumeráveis viagens, assume como sua essência própria o ser nada mais do que um ponto, cambiante, no qual linguagens confluem antes de outra vez prosseguirem em sua dispersão cintilante. O relato, desta maneira, em que a personagem atua como inequívoca persona, máscara, dá as costas à epopeia e se apresenta como uma genuína prosopopeia, um canto cuja harmonia contempla um incessante devir-prósōpon, pautado pelas suas incessantes transformações, uma em seguida de outra. Resulta um movimento sincopado que acena para o trabalho de Sísifo antes aludido, agora transfigurando-se, contudo, na série

\footnotetext{
${ }^{26}$ MONDZAIN, Marie-José. A imagem pode matar, op. cit., p. 25.

27 KRACAUER, Siegfried. History: the last things before the last. Ed. Oskar Kristeller. Princeton: Markus Wiener, 1994, p. 157.
} 
dos sem-sentidos que, pulsando desde a esfera da literatura e da arte, tangenciam a sempiterna impossibilidade de um sentido definitivo, de qualquer possibilidade de finalização ou de realização efetivas, à parte aquelas com as quais a violência nos quer perenemente violentar.

Em função do poder de se metamorfosear que lhe é inerente, Ahasverus mostra-se apto a assumir a situação, e o papel, não apenas de qualquer ser mas ainda de todo ente ou entidade do mundo, em qualquer momento e lugar. Através dessa estratégia, a narrativa, em que ele se constitui enquanto corpo de palavras, rompe o fio do tempo cronológico, retilíneo, e adentra, configurando-a, a temporalidade específica do registro artístico, um tempo de gostos, gastos e gozos, ocaso do tempo, conjunção prodigiosa de memória e porvir. A personagem, com isso, pode em dado momento ser Marc Chagall, em Paris, meditando sobre aquela que seria a "Crucificação branca", tela de 1938, em outro o mestre Domingues, personagem central de "A abóboda", das Lendas e narrativas, de Alexandre Herculano, ou ainda surgir, na Amsterdã do século XVII, como o velho Baruch Espinoza, "estirado num leito" e cercado pelas suas "ferramentas para polir lentes". ${ }^{28}$

A impossibilidade da degradação física e da morte articula-se a essa capacidade metamórfica da personagem, o que possibilita ao texto alcançar uma dinâmica especial, pautada por um ritmo cuja alucinação, e caráter vertiginoso, é expresso pela alternância constante de metamorfoses e, nos interlúdios por elas proporcionados, por incessantes deslizamentos espaço-temporais, tudo isso exposto numa prosa entrecortada, repleta de envios a e desvios de situações ou indicações à primeira vista disparatadas. Embora a novela seja em grande parte formada por um único bloco, apenas interrompido, próximo ao desfecho, pela presença de duas imagens e pela abertura de um único segundo parágrafo, nele nexos de causalidade, de sequenciamento temporal ou contiguidade espacial são amiúde desfeitos, ou, no mínimo, fracionados. As "Viagens de Ahasverus", portanto, atestam uma consistente exploração de mecanismos baseados na elipse e na transitoriedade, despontando daí, desde faltas ou falhas como tais, um relevo aventuresco e uma forte sensação de

\footnotetext{
${ }^{28}$ RAWET, Samuel. Viagens de Ahasverus à terra alheia em busca de um passado que não existe porque é futuro e de um futuro que já passou porque sonhado. In: Contos e novelas reunidos. Org. André Seffrin. Rio de Janeiro: Civilização Brasileira, 2004, p. 471. Como todos os fragmentos adiante transcritos referem-se a essa edição, a referência às páginas de onde foram retirados serão colocadas após as citações, entre parênteses.
} 
inacabamento que contaminam seus diversos níveis narrativos.

No âmbito da discussão aqui proposta algumas cenas de "Viagens de Ahasverus" alcançam particular relevância. Uma delas acontece num passado pouco definido, com a personagem sendo julgada em um tribunal cuja descrição remete claramente à Inquisição. Ahasverus está "diante de alguém, uma autoridade" a informar-lhe que, "se durante a tortura viesse a sofrer algum acidente, a culpa seria toda dele". Num raciocínio "cheio de filigranas lógicas e torneios labirínticos", o inquisitor afirma ser "um dos dois... culpado, já que pensavam de modo diverso", ressalvando, contudo, que o "único a assumir a culpa seria ele, Ahasverus". A resposta deste é dada por uma "avalanche de metamorfoses incompletas" até que, "ao assumir a forma de íncubo e depois súcubo, e nas duas formas de súcubo e íncubo", passa a

exalar um cheiro de esperma e enxofre, produto de uma sexualidade desbragada, insatisfeita, permanente, ávidas sempre as duas formas de gozo, e no auge do gozo desejando mais gozo, tanto gozo que as formas eram insuficientes, e se multiplicaram. (p. 462-463)

Um outro episódio ocorre no futuro, "um futuro bem remoto", como anota o narrador, em que a personagem, desinteressada de saber da roupa de "hidrotecidos... de cores cambiantes", das "casas flutuantes construídas pelo princípio já esclerosado da antigravitação", e das divagações sobre "os campos das construções ideais", das "funções hiperzeta" invadindo o campo da "csiologia" e da "ontonomia", sente-se farto de tudo e, buscando contemplar a "exigência interna do ser, e o estabelecimento de um sentido pessoal de ética", começa "pelo corpo", "corpo imediato, dotado de apetites e capaz de se organizar em consciência ávida de mundo". Então: "Alisou os cabelos, esfregou o rosto, desceu com satisfação as mãos pelo peito e ventre e segurou o membro com intensa euforia, depois sentindo uma leve irritação na região glútea afagou o ânus com o dedo médio". Na sequência ele se entrega "ao gozo sensual da aragem na pele", e quando estava ainda "a gozar as delícias da brisa" é preso pelo "Instituto de Segurança Individual". Após um breve interrogatório, durante o qual fica sabendo que "todas as ideias que lhe ocorreram" enquanto se entregava à satisfação de suas sensações corpóreas haviam sido registradas, não encontra outra alternativa "a não ser lavrar a própria sentença, de Morte Singular", uma "longa hibernação e restruturação das células nervosas", das quais logra escapar quando, ao adormecer, "e não hibernar", 
que era o que dele se exigia, no sono consegue "um produto bem mais arcaico chamado sonho" (p. 466-469).

A exemplo do que ocorre na cena há pouco comentada, de Bent, também aqui o corpo, enquanto mancha que se dissipa em gozo e imagens oníricas, produtos de uma inelutável intimidade que com seu aflorar desafia a autoridade e suas práticas anestésicas, abre-se em válvulas de onde vaza um desvio e um envio ínfimos, com o que o jogo e o jugo arbitrários são confrontados. Em momentos como estes, torna-se possível reconhecer o contraste entre aquela relação espacial e pessoal, identificadora e impressa por uma força exterior, característica do signo e do desenho, e aquela relação estabelecida pela mancha, "que se inscreve no tempo, no próprio corpo, e unicamente nele, antes de se expor". Um fenômeno, como acrescenta Jean-Louis Déotte, "que releva de um mimetismo originário, como o enrubescimento decorrente de uma transgressão da lei." ${ }^{29}$

Mas o caráter-mancha do protagonista plural da novela é também reiterado num momento em que a personagem entretém um ato sexual, digamos, convencional. No caso, durante a conjunção carnal com uma mulher qualquer, com quem não troca uma única palavra ("Não houve palavras"). Ato que, graças a seus "extremos do gozo", leva Ahasverus a "redescobrir poro por poro as relações superfície externa e mente", e revela a ele "recursos de mucosas" que Ihe oferecem "a condição de estender a noção de superfície exterior com a de interior, contínua, e os orifícios seriam apenas singularidades de uma continuidade desconhecida para as aparências" (p. 470-471).

A passagem indica que, para a personagem mimética, o semblante parece constituir não uma simples figuração a ser negada ou menosprezada, mas uma configuração que deve ser guardada com zelo, e aguardada. Isso justo por ela apontar para uma confluência particular entre aparência e não-aparência, entre evidente e inevidente, que torna possível, como expõe Raul Antelo, que "o sujeito capte seu gozo fora de sentido ou, em outras palavras, para que meça o verdadeiro com o real. Essa elucidação, mais que a transparência do sentido, desvela qual tem sido o vínculo do semblante com o gozo opaco de quem fala." ${ }^{30}$ Não seria possível encontrar no gozo silente de Ahasverus, e

${ }^{29}$ DÉOTTE, Jean-Louis. Benjamin, le corps de la couleur. In: L'Homme de verre: esthétiques benjaminiennes. Paris: L'Harmattan, 1998, p. 108.

${ }^{30}$ ANTELO, Raul. Subjetividade, extimidade. Boletim de Pesquisa NELIC, Florianópolis, v. 9, n. 14, 2009, p. 55. 
naquele das personagens de Bent, seguindo ainda as reflexões de Raul Antelo, uma sorte de compreensão, isto é, "uma experiência que, longe de fazer ressoar o corpo enquanto imaginário, é capaz de fazer ressoar uma conexão com o buraco, próprio da identificação ao sintoma"? ${ }^{31}$

Nesse quadro o conceito de extimidade, formulado por Jacques Lacan, mostra-se valioso, na medida em que ele coloca em tela de juízo exatamente a situação liminar que o trânsito entre interno e externo - cuja fluência difusa, avessa à palavra, torna sensível a existência de um sem número de aberturas à flor da pele, orifícios, poros, dobras e inflexões nas quais dentro e fora se indistinguem, como intuído por Ahasverus - introduz no organismo da novela. A extimidade, afinal, tal como a mancha, ao invés de se restringir a uma contraposição binária entre cerne e superfície, ou subjetividade e objetividade, permite pensar em termos de campos de força, ou zonas de contato e contágio. Possibilita, enfim,

estabelecer que o mais interno, o mais íntimo, encontra-se, paradoxalmente, no exterior, no exposto e no aberto, e assinala sua presença segundo o modelo de um corpo estranho que reconhece uma ruptura constitutiva da intimidade. Não se trata, assim, do espaço marcado e separado pela imagem, o imaginário, mas sim de uma topologia que permite situar o que vacila entre interior e exterior, o real. $^{32}$

A mancha, o gozo e também a capacidade da linguagem correspondem ou são matrizes de eventos estranhos no ou ao corpo: não são próprios dele, nele não se mantêm, pois apenas o perpassam e, por conseguinte, situam-se fora da lei, a que não cansam de desafiar. Seja como for, como antes colocado, um indivíduo não pode ser positivamente determinado ou em definitivo identificado apenas com base neles, fugazes acontecimentos que são, faculdade essa que é mais própria do signo e do desenho, conforme realçou Walter Benjamin.

Os sonhos e gozos que atravessam Ahsverus constituem antes de tudo, porquanto emanações, respostas urgentes, e ousadas, com as quais num primeiro momento a personagem confronta o assédio, a ele se contrapondo, de funcionários de corporações quaisquer que, seja no pretérito ou no futuro longínquos, arrogam-se o direito de legislar, vigiar e, atitude sempre culmi-

\footnotetext{
31 Ibidem, p. 56.

32 Ibidem, p. 61, nota 13.
} 
nante, punir. Aflorando em seu corpo, a rebeldia faz com que ela expie as culpas que lhe são imputadas, imputação essa que constitui a razão de ser daquelas instituições com que se vê defrontada. Por um paradoxo apenas aparente, entretanto, as acusações que sobre ela recaem consistem exatamente naquilo que, desde o seu ponto de vista, culpabiliza as corporações, uma culpa imperdoável, imprescritível e inexpiável.

“Lá onde não se pode 'fazer' nada, pode-se ao menos ressentir, inesgotavelmente", adverte Vladimir Jankélévitch. A categoria de ressentimento, cuja manifestação é expressa, dentre outras maneiras, pelo sentimento "renovado e intensamente vivido da coisa inexpiável... protesta contra uma anistia moral que nada mais é que uma odiosa amnésia", permitindo assim que seja mantida acesa, segundo o autor, "a flama sagrada da inquietude e da fidelidade às coisas invisíveis". ${ }^{33}$ Não seria o pensamento, no âmbito da novela de Samuel Rawet, uma dessas primordiais "coisas invisíveis" que, ameaçadas pelas corporações com que se defronta, motivam as reações intempestivas e diabólicas de Ahasverus, fazendo dele um ressentido? Na narrativa, afinal, o pensar distintamente é o móvel principal que baseia a acusação do inquisitor ("já que pensavam de modo diverso", afirma este, "no caso o único a assumir a culpa seria ele, Ahasverus" (p. 462)). Já no episódio situado no futuro, a inculpação da personagem decorre, de um lado, do fato de a personagem ter dado livre curso às sensações que lhe percorriam o corpo, e, de outro, das ideias que então teve (o funcionário do "Instituto de Segurança Individual" mostra a ele, na cena, uma "pasta que registrava todas as ideias que lhe ocorreram desde o instante em que fora à faixa plástica que dividia as áreas de verde sintético" ( $p$. 469)).

Por isso, na sequência das duas cenas, Ahasverus, além de gozar, e sonhar, formula uma série de questionamentos que confluem na assunção de sua condição transitória, débil e inoperante, porém ressentida. Na primeira delas, no passado, responsabilidade e culpa são por ele considerados fenômenos antitéticos, de maneira que a existência plena da primeira necessariamente implica no apagamento da segunda. Resulta que, em sua perspectiva, a ausência de culpa torna-se um possível lugar comum que poderia reunir uma humanidade finalmente responsável, e não unicamente responsabilizável, uma humanidade

${ }^{33}$ JANKÉLÉVITCH, Vladimir. Pardonner?, op. cit., p. 62. 
desejante, inclusive de consciência. Uma operação cujo sucesso, no limite, poderia levar à quebra de uma das molas mestras do mecanismo em que se baseia o poder corporativo, conjugado como uma terceira pessoa ${ }^{34}$ :

Ao exigirem dele a responsabilidade de algo a culpa desaparecia, tanto dele como do outro. E restava apenas a iniquidade de um jogo de valores. Ahasverus teve vontade de gritar, vontade apenas: sou responsável pelo que vejo, ouço, aspiro, degusto, toco, penso, imagino, sou responsável pelos meus desejos ainda informes, pelas ideias que se transformaram em atos, pelos atos que se transformaram em ideias, mas enquanto meus, apenas, nada tenho com o ato dos outros que me desloca a consciência, mas tenho com a consciência. (p. 463)

Na segunda cena, no futuro distante, o fluxo de sensações corpóreas conflui numa reflexão que, por sua vez, leva à interpelação da própria concepção de culpabilidade: "Partindo do princípio de que era responsável pela respiração, digestão, defecção, pelos seus passos, pelo olhar, pelas ideias que tinha, reformulou a noção de culpabilidade" (p. 469). Tal processo alcança seu clímax quando Ahasverus se indaga, logo após ter se metamorfoseado, note-se, em Espinoza, sobre a "necessidade ou a possibilidade da existência de um Deus, ou de um deus". E conclui, em resposta à indagação, acusando este Deus ou deus de atuar em benefício não da libertação, mas da submissão dos seres:

\footnotetext{
Um infinito sentimento de culpa, uma desculpa para fugir à própria responsabilidade dos atos que compunham seu cotidiano num universo que escapava à sua compreensão porque ele, ou qualquer outro, era apenas o que era, um ser dotado de consciência e de responsabilidade de ser consciência, um criador permanente de realidades singularizadas em conflito com outras realidades singularizadas. (p. 471)
}

Considerado pelo que traz em si de mancha, isto é, como uma figura avessa a algum contorno de uma vez por todas definido, como alguém que não se deixa determinar por linha alguma, uma intermitência, Ahasverus, em suas andanças, não para de encontrar potências estranhas a ele, com as quais, no entanto, entretém uma relação menos de aparência que de contiguidade, so-

\footnotetext{
${ }^{34}$ A categoria da terceira pessoa, aqui, remete à análise realizada por Roberto Esposito em Tercera persona: política de la vida y filosofía de lo impersonal. Trad. Carlos R. Molinari Marotto. Buenos Aires: Amorrortu, 2009.
} 
bretudo quando colocadas diante da lei, a que todas elas se contrapõem. São as personagens potências em que se metamorfoseia, todas elas manchadas, e que por isso mesmo apontam para uma potência especial que, para retomar ainda outra vez os termos de Walter Benjamin, "mantendo sua neutralidade... encontra seu lugar dentro da mancha mesma, sem desintegrá-la, precisamente por ser incomensuravelmente superior a ela, não lhe sendo, no entanto, hostil, mas afim." ${ }^{35}$ Tal potência é a palavra, ou melhor, o nome, resignado ao designar.

O desdobrar-se em uma série de nomeações que evocam acontecimentos, lugares, entes e pessoas, tanto históricos quanto ficcionais, faz com que Ahasverus se incorpore a e ao mesmo tempo seja incorporado por tudo aquilo que estas nomeações apresentam. Tais corpos eventuais, corpos de letras que evocam as manchas neles aparentes, manchas nas quais, vale repetir, "a resistência do presente entre o passado e o futuro é eliminada" ${ }^{36}$, magicamente, porquanto resíduos, memórias, não deixam de voltar a acontecer, de reverberar num agora inabordável, porém diferidos, constituindo então um outro do mesmo, isto é, um outro mesmo.

São os nomes que trazem consigo potência de, como nas composições pictóricas sobre as quais reflete Benjamin, remeter a uma série de outras singulares impalpabilidades que permeiam a novela. Além daquelas há pouco citadas, é o caso de Johan Sebastian Bach, com a menção à Chaconne da Partita $n^{\circ} 2$ em Ré menor e à Cantata Fúnebre Gottes Zeit ist die allerbeste Zeit (O tempo de Deus é o melhor de todos), também conhecida como Actus Tragicus; ou William Shakespeare, com Romeu e Julieta; Bernard Shaw, com Santa Joana; Miguel Torga, com "Vicente", o corvo; Herman Hesse, com Demian e Sidarta; ou Thomas Mann, com a Morte em Veneza, para citar algumas das demais criações artísticas ali convocadas. Nomes que invocam invisíveis supremos e irredutíveis: palavras, sons, deuses e morte, cuja modernidade, ou pertinência para o pensamento da modernidade, advém em muito do fato de que, a exemplo do que segundo Benjamin ocorreu nas pinturas do início do século $X X$, trazem consigo um julgamento, isto é, uma ética. Tal como ocorre no âmbito da imagem pictórica, que, como o autor argumenta, "só é mancha na própria pintura", e, "ao ser nomeada, é relacionada a alguma coisa que ela pró-

\footnotetext{
${ }_{36}^{35}$ BENJAMIN, Walter. Sobre a pintura ou Signo e mancha, op. cit., p. 86.

36 Ibidem, p. 84.
} 
pria não é", Ahasverus encontra, na novela, a "força... da palavra da língua". A posição da personagem, através de quem "a palavra que julga" 37 é aquela que mais penetra, é na verdade uma simples com-posição, uma relação permanente de desapossamento de si-mesmo, o seu abandonar-se a algo ou alguém que ele não é, mas advém, mesmo por apenas um átimo. Ela se mostra como um si que de si desliza, que vai ao encontro de outros, que se compõe com outros e se contrapõe a outros de si, outros se.

"O real precisa ser ficcionado para ser pensado", defende Jacques Rancière, que por outro lado critica a mera oposição entre o antigo e o moderno, pois para ele "o futuro da arte, sua distância do presente da não-arte, não cessa de colocar em cena o passado". Advém daí a temporalidade especial do regime estético das artes, por ele postulada, implicar numa "co-presença de temporalidades heterogêneas". ${ }^{38}$ A ficção das "Viagens de Ahasverus", ao se armar a partir de uma série de vestígios das artes, com base nisso que nos resta da ou como a arte, expressa a seu modo a inelutável importância do arquivo ou da coleção para a existência, em fugaz permanência, do acontecimento que chamamos arte, esse singular que embute sempre um plural, mesmo que este permaneça não declinado. A personagem com quem sonhou Kracauer aparece divagando, na novela firmada por Samuel Rawet, e suas andanças produzem a abertura de um sem número de dutos de passagem, pelas quais a memória, escrita, musicada, pintada ou imaginada, escoa livremente, e pode, assim, ser re-apresentada, desdobrada. Ahasverus, então, traz consigo a potência de deparar-se ainda, por exemplo, com Farenheit 451, o livro de Ray Bradbury (1920), e com o filme homônimo de François Truffaut (1966) dele derivado, ambos com seus personagens-texto que asseguram a rememoração, ou seja, arquivo, e com ela uma débil resistência contra uma opressão que segue sempre uma mesma e reta linha, com o intuito, porém, de apagá-las ambas, para o que se serve dos mesmos ferro e fogo com que marcam ou aniquilam os corpos. E aí começaria outra história, outro futuro improvável.

\footnotetext{
37 Ibidem, p. 86-87.

38 RANCIËRE, Jacques. A partilha do sensível: estética e política. Trad. Mônica Costa Netto. São Paulo: EXO/Editora 34, 2005, p. 58, 35 e 37, respectivamente.
} 